\title{
「さしものづくり」における小屋荷重の伝達経路からみた 架構の変化過程
}

石川県鹿西町周辺の木造住宅における軸組と小屋組の関係

\author{
THE PROCESS OF TRANSFORMATION OF FRAMING SYSTEM \\ IN “SASHIMONO-ZUKURI” FOCUSSING ON THE ROUTE OF LOAD \\ TRANSFER FROM ROOF FRAME TO MAIN FRAME
}

Research on the correlation between main frame and roof frame of timber houses at Rokuseicho, Ishikawa prefecture

\author{
堀江 亨*, 茶谷正洋**,八木幸二*** \\ Tooru HORIE, Masahiro CHATANI and Köi YAGI
}

\begin{abstract}
This paper deals with the correlation between main frame and roof frame of timber houses at Rokuseicho,Ishikawa prefecture, analyzing quantitatively the route of load transfer from roof frame to main frame. It revealed that the average height of the route shifted upwards in main frame. In case of thatched roof, the process of expanding openness to the side of frame appeared in transformation of main frame. In case of tiled roof from the beginning,the arrangement of various type of beams has been developed either to show pile of beams or to expand openness upwards within main frame.
\end{abstract}

Keywords: roof load, main frame, roof frame, changing roof frame 小屋荷重, 軸組, 小屋組, 屋根替え

1.はじめに

本研究は, 石川県鹿西町周辺”の木造住宅における軸 組と小屋組の関係を，小屋組を支持するための軸組の部 材構成に着目することにより数量的に表現し，その変化 過程を明らかにすることを目的とする。分析対象は，鹿 西町周辺において，丸太を太鼓にした「さしもの」 ${ }^{2)}$ 称する梁材に特徵づけられた住宅とする。分析資料は, 江戸中期から昭和 60 年までに建てられた 38 棟の実測調

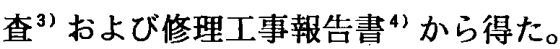

本研究では, 軸組において小屋組の鉛直荷重（以下, 小屋荷重と呼ぶ）が伝達される部材構成を荷重経路之呼 びここれを，小屋組の下端之析の位置関係および軸組内 部の部材構成の相違により分類し，小屋荷重が経由する 部材数により軸組と小屋組の関係を表現するものである。 なお，本研究における荷重経路という語については，部 材の位置関係と空間構成の関連を明確にするために用い ており，構造力学における荷重の量や配分方法の考え方 を適用していない。また，自重や床荷重との関連につい
ても，小屋組の支持方法を分析する本研究の趣旨により 考慮外としている。

\section{2. 調查住宅の概要と分析の手順}

図一 1 に示すように，調查住宅の軸組架構は，「さし もの」を中心とし，柱，析，「ひらもの」（現地の呼称 で差鴨居のこと），束，貫などにより構成される「さし ものづくり」と呼ばれる井楼形の単位架構が複数集合し て成り立っており，平面構成におおむね対応している。

調查住宅の屋根形式には，入母屋草草で平入りの「く ずや」，および切妻瓦苜で妻入りの「あづまや」と，平 入りの「ひらや」が見られる。内部の小屋組は，「くず や」が双首組，「あづまや」，「ひらや」が，束を用い た小屋組としており, 後者については, 図一 1 に示した 登り木を用いた構成のほかに, 和小屋としているものも 見られる。調查住宅の一部の家屋においては, 双首組に よる草苗を, 束を用いた小屋組による瓦惪に改变してお
${ }^{*}$ 日本大学農獣医学部林学科 助手 $\cdot$ 工博

** 東京工業大学 名誉教授・工博

*** 東京工業大学工学部建築学科 助教授 $\cdot$ 工博
Research Assoc., Dept. of Forestry, College of Agriculture and Veterinary Medicine, Nihon Univ., D. Eng. Emeritus Prof., Tokyo Institute of Technology, Dr. Eng. Assoc. Prof., Dept. of Architecture, Faculty of Eng., Tokyo Institute of Technology, Dr. Eng. 


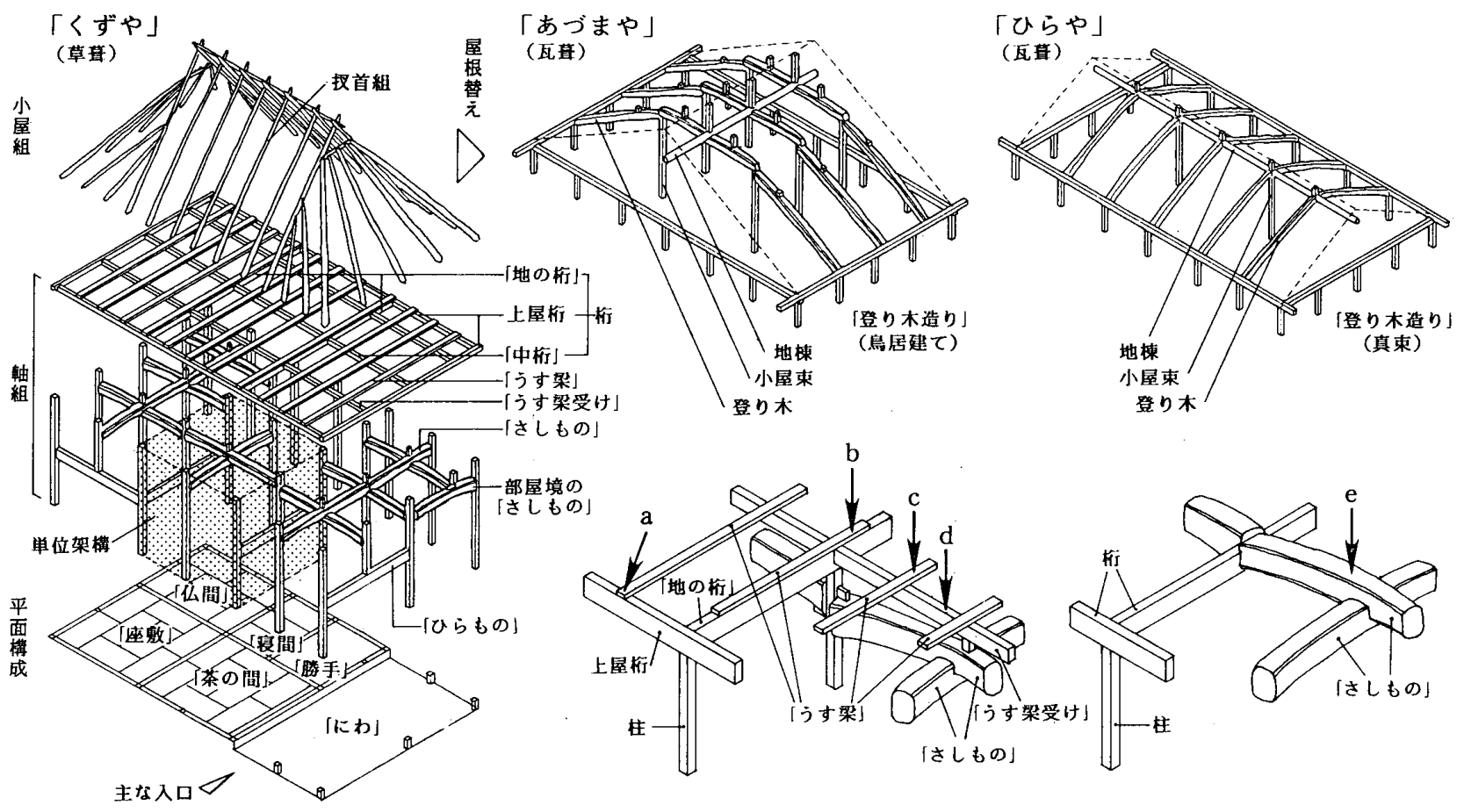

図-1 調查住宅の架構概要

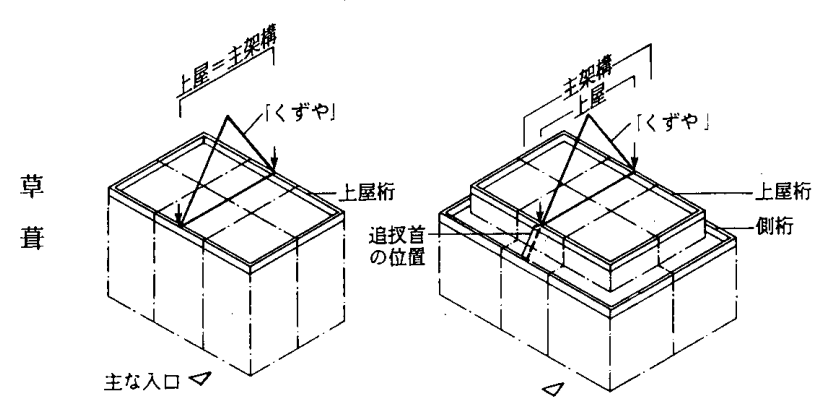

屋根替え ((8))

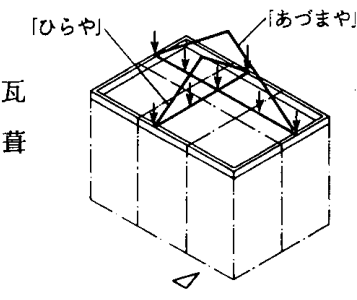

「すや」
屋根替え $¥((4))$

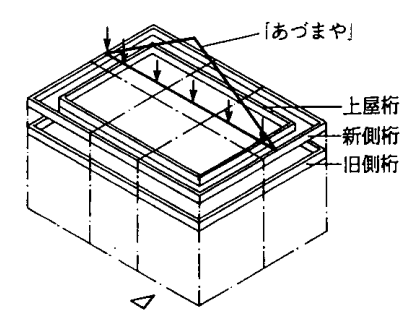

「まえいえ」

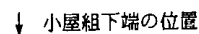

図-2 屋根形式の分類

表 -1 各架構形式の棟数

\begin{tabular}{|c|c|c|c|c|c|}
\hline 屋根形式 & 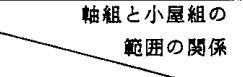 & 「すや」 & 「まえいえ」 & \multicolumn{2}{|c|}{ 旪 } \\
\hline 幹のまま & 「くずや」 & 0 & 3 & \multicolumn{2}{|r|}{3} \\
\hline 草基加瓦基 & 「くずや」 & 5 & 4 & 9 & \multirow[b]{2}{*}{12} \\
\hline 人屋根替え & 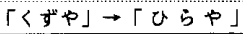 & 3 & 0 & 3 & \\
\hline 㳡工当初から & 「あつまや」 & 14 & 0 & 14 & \multirow[b]{2}{*}{23} \\
\hline 㼛 & $\lceil ひ ら ゃ 」$ & 9 & 0 & 9 & \\
\hline & 就 & 31 & 7 & & 38 \\
\hline
\end{tabular}

り,これを現地では屋根替えと呼んでいる。なお，屋根 替えの際には，軸組の部材構成は変化していない。 「くずや」の軸組上端には, 図一 1 に示すように, 上 屋")外周の桁 (以下上屋桁之呼ぶ) 以外に, 単位架構の 境界に「地の桁」，「中桁」之呼ばれる桁が柱頭をつな いで縱横にかかっている ${ }^{6)}$ 。草直朴よび屋根替え住宅で は，「中桁」に並行し，これよりやや断面の小さな「う す梁受け」》がかかりここれを下部の「さしもの」に立 てられた束により受けている。また，「うす梁受け」と 直角方向には五平の「うす梁」 ${ }^{8)}$ が渡る。「うす梁」は 小屋裏の林下地になるとともに, 草苜では, 図- 1 の矢 印 $\mathrm{a}$ に示すように, 両端の上屋析の通りで双首尻を受け ている。また, 屋根替え後に小屋束の立つ位置には， b のように，析上の「うす梁」で受ける場合，cのように， 下部に支持のない「うす梁」で受ける場合，dのように, 「うす梁受け」で受ける場合が見られる。また, 当初か らの瓦葷では，e のように，析回りの高さにかけられた 「さしもの」により小屋束を受ける場合がある。

図一 2 には, 調查住宅を, 上屋の範囲と下部の単位架 構による軸組の範囲（以下，主架構と呼ぶ）が一致する 「すや」と，上屋の四方に主架構が張り出した「まえい え」に分けて屋根形式との対応を示し9), また, 表一 1 には該当する棟数を示した。図一 2 に示すように，「ま えいえ」は，草草時には上屋の外側に追双首のとりつく 形式としており, また，屋根替え時には，側枌と呼ばれ る主架構の外周に回る桁の上に新たに桁を加え, これを 梁間として小屋組を載せているため, 上屋の範用が拡大 
している。また, 図一2には, 各々の屋根形式において 双首尻または小屋束下端（これらを併せ以下，小屋組下 端と呼ぶ）の立つ位置を例示した。調查住宅においては, 草苜時に双首台であった「うす梁」が屋根替え時にも残 り，屋根替え後または当初から瓦苴において小屋束を受 けている場合がある。本研究では,こうした「うす梁」 の働きにおいて架構法の変化が端的に表れると考え，こ れを小屋荷重を受ける軸組部材に含めて分析する ${ }^{01}$ 。

本研究では, 図ー2に示したような小屋組下端の各点 ことに小屋荷重が経由する軸組部材を考えるものとし， 小屋組自体の構成上の相違を考虑外とする。ゆえに，上 屋と主架構の範囲の相違による「すや」と「まえいえ」， および，小屋組下端の位置の相違による草莫，屋根替え 住宅，当初からの瓦草の各形式を比較の対象とする。な お，「あづまや」と「ひらや」については，棟方向およ び小屋構面の形状は異なるが，本研究の着眼点である小 屋束の位置と軸組部材との対応関係において同等に扱う ことができるため，以下の分析において「あづまや」と 「ひらや」の区別を行わないものとする。

分析の手順を述べると, まず, 単位架構における小屋 組下端の位置を，析との関係から分類する。次いで，析 回りにおいて小屋組を支持する部材とその下部の軸組内 部の部材構成から, 小屋荷重の伝達経路の類型を抽出し, 各層における経由部材数を数值化する。最後に, 調查住
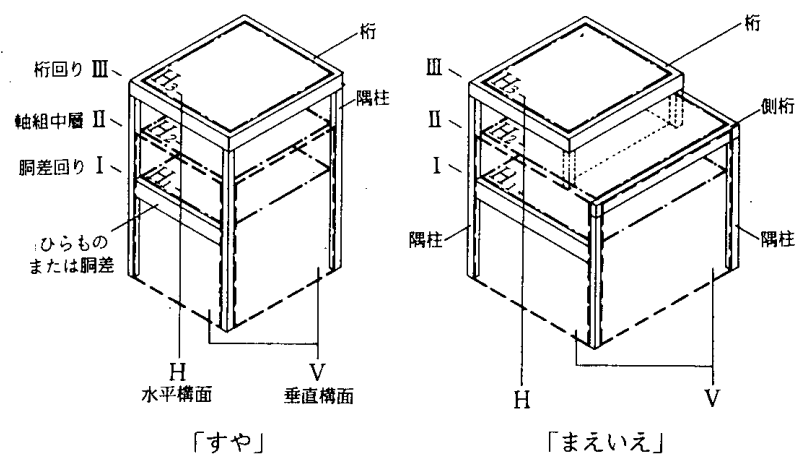

図-3 単位架構における層区分と軸組構成要素
宅における荷重経路の分布を屋根形式ごとに求放, 全体 架構における軸組と小屋組の年代変化の傾向を考察する。

\section{3. 小屋組の位置の分類と荷重経路の類型化}

\section{(1) 用語の定義}

図ー3に示すように，軸組における高さの区分として， 軸組上端の桁回り，「ひらもの」あるいは胴差のかかる 胴差回り, および両者の中間の軸組中層の 3 層を定め, これらを下方から層区分 I，II，III とする。また，軸組 の基本的な構成要素として, 隅柱, 桁のほかに, 各層区 分における梁組の構成を水平構面 $\mathrm{H}_{1}, \mathrm{H}_{2}, \mathrm{H}_{3}$, お よび四周の側面の部材構成を垂直構面 $\mathrm{V}$ と定め, これら を併せて軸組構成要素と呼ぶ。図に示すように，「まえ いえ」では, 軸組中首の水平構面 $\mathrm{H}$ ， が側方に張り出し, 桁回りの水平構面 $\mathrm{H}_{3}$ よりもその範囲が広くなっている。

なお，「まえいえ」における側析は，小屋組の主体部 分を直接受けておらず，その下方にあって「さしもの」 を通じて間接的に荷重を受けているため，桁とは見なさ ないものとする ${ }^{11}$ 。また, 本研究では, 垂直構面の働 きを，隅柱に支持されていない析，および水平構面 $\mathrm{H}$ ， , $\mathrm{H}_{2}$ の部材端を支持するものと考え, 両端が隅柱に支持 されている析との関係は考慮しないものとする。なお， 調查住宅において, 水平構面 $\mathrm{H}$ ，は，もっぱら 2 階床の 下地として働き, 小屋荷重の経路になっていないので, 本研究では, 垂直構面と水平構面の間に生ずる荷重経路 としては, 軸組中層の水平構面 $\mathrm{H}_{2}$ を経由したもののみ を报う。

図一 4 には, 単位架構の構成要素に属する軸組部材を 挙げ，またこれらの部材の配される層区分を示すとと もに, 各部材を記号により略記した。水平構面には, 「さしもの」,「うす梁受け」,「うす梁」が属し, 垂 直構面には，隅柱間に立つ中間柱，「ひらもの」，部屋 境の「さしもの」，および「まえいえ」における側桁が 属する。このほかに, 単位架構の内部に立つ独立柱が考 えられるが，調查住宅には見られなかった。

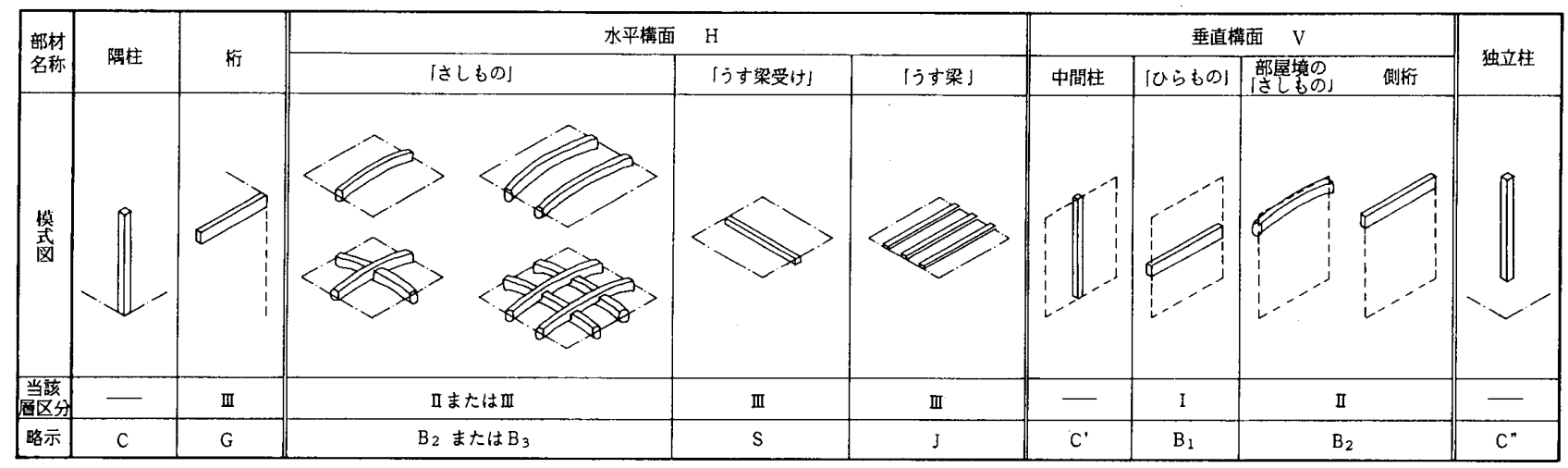

図一 4 軸組部材の分類 
（2）小屋組下端の位置の分類

図一5には，「すや」と「まえいえ」における単位架 構と，小屋組下端の位置を示した。1は「すや」に対応 し，上屋と主架構の範用が一致する場合， 2 および 3 は 「まえいえ」に対応し；上屋範囲に対する主架構の張り 出しが一方向および二方向の場合を示している。図-6 には，図一 5 において想定される小屋組下端と桁との位 置関係の種類を，桁よりも下方の軸組部材の支持形式を 考慮して分類した。すなわち, 小屋組下端の位㯰には, 析隅，析筋，析内の 3 種が考元られ，小屋組下端が析隅 に位置する場合のうち，隅柱上に位置する場合を $\alpha$ ，垂
直構面上である場合を $\alpha^{\prime}$ ，軸組中層の水平構面上であ る場合を $\alpha$ ”とする。また，小屋組下端が析筋に位置す る場合のうち，析の両端が隅柱に支持されるるのを $\beta$, 析の片端が隅柱に支持されるものを $\beta^{\prime}$ ，析の両端が隅 柱に支持されないものを $\beta^{\prime \prime}$ とする。一方，小屋組下端 が析内にあれば，図－5の1〜3のいずれの場合も水平 構面 $\mathrm{H}_{3}$ に支持されるので $\gamma$ は一種類の分類とする。

図一6には，各々の分類において，軸組の構成要素 $\mathrm{G}$, $\mathrm{H}_{2}, \mathrm{H}_{3}, \mathrm{~V}, \mathrm{C}$ $う ち$, 小屋荷重の経由するものを 示している。なお，柱頭にかかる荷重については，その 頂部に水平材が載うている場合を，柱の頂部に直接荷重

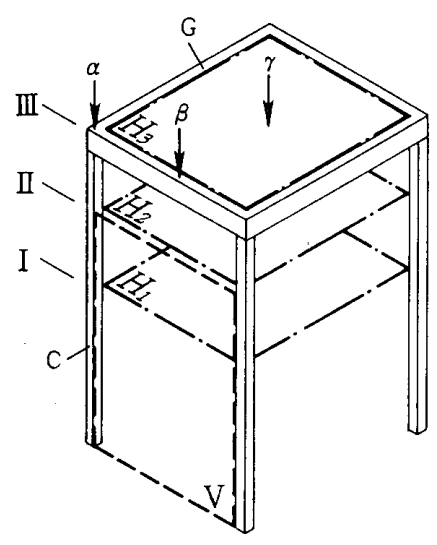

1

「すや」

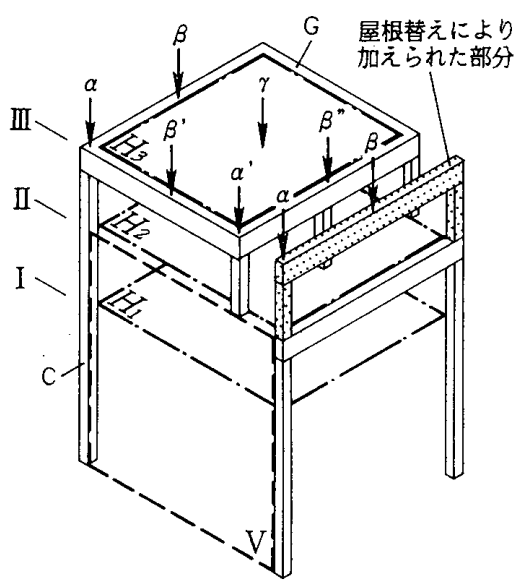

2

「まえいえ」

上屋に対する主架構の張り出しが一方向

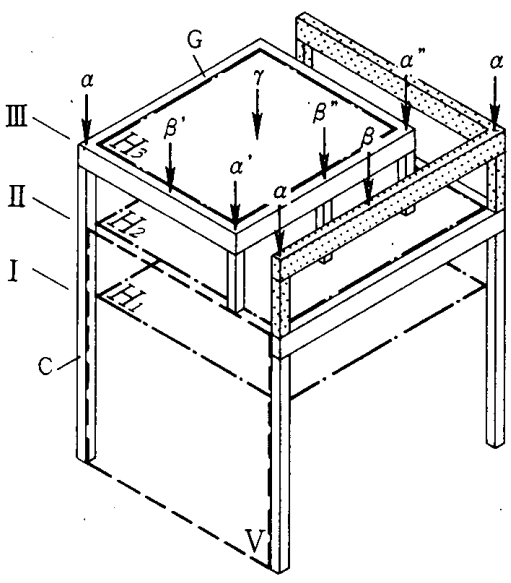

3

「まえいえ」

上屋に対する主架構の張り出しが二方向

図ー5 単位架構における小屋組下端の位置

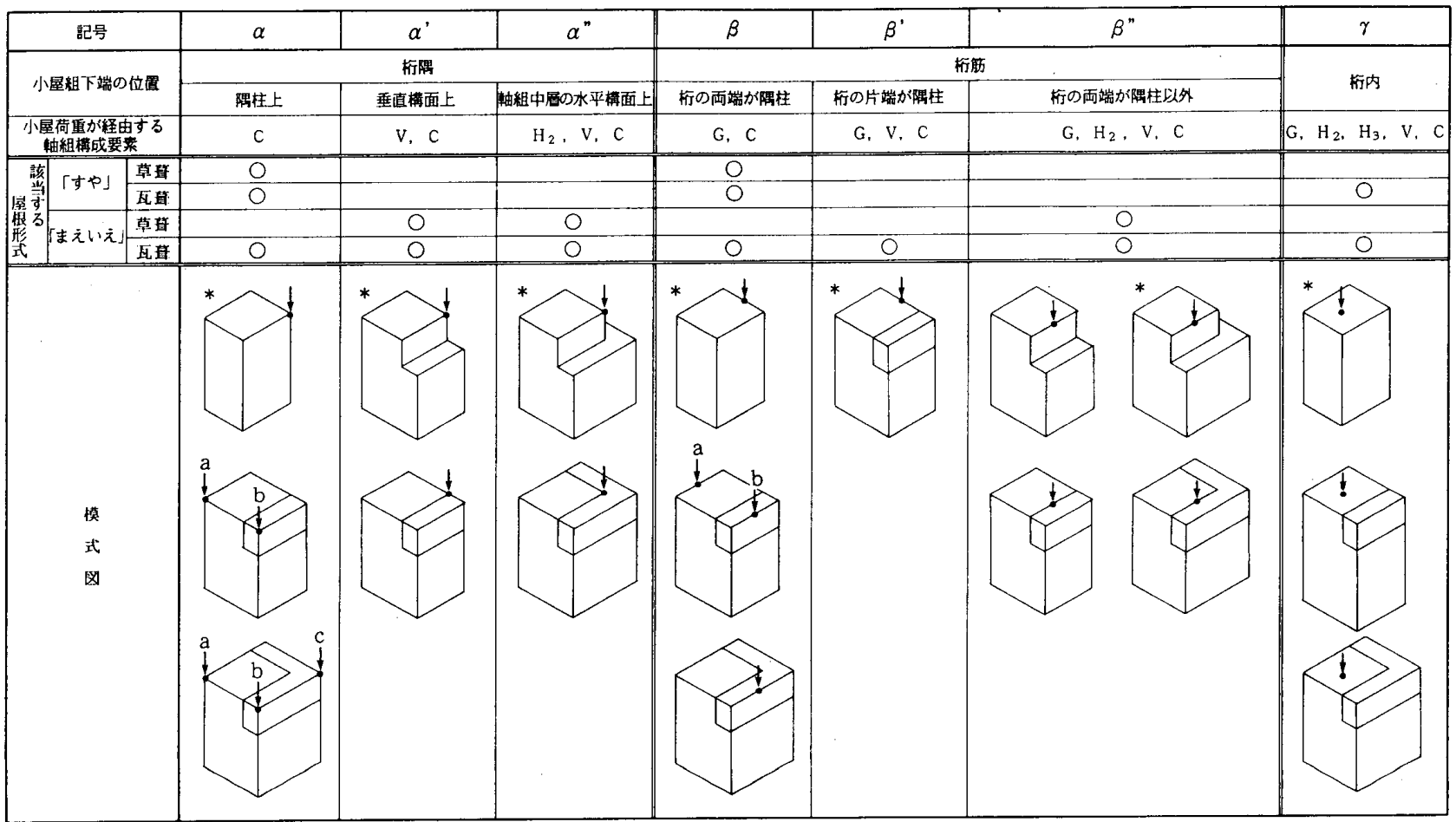

図-6 小屋組下端の位置の分類 
がかかる場合と同等に見なす。すなわち，図一 5 の析隅 $\alpha$ は隅柱の真上に位置しているので, 小屋組下端は桁の 上に載っているが，荷重は桁を経由せず，隅柱に直接伝 わるものとする。また，図一6には，各分類について 「すや」，「まえいえ」の各々における，草惪，瓦莫の
対応を模式図とともに示した。すなわち，草草の「すや」 では，双首尻は必ず析上に載るので $\alpha, \beta$ が対応し，草 革の「まえいえ」には，双首尻が主架構の張り出した側 の析上に位置するので $\alpha^{\prime} ， a^{n} ， \beta^{n}$ の3 分類が対応 することになる。瓦苜の「すや」には, 主架構の張り出

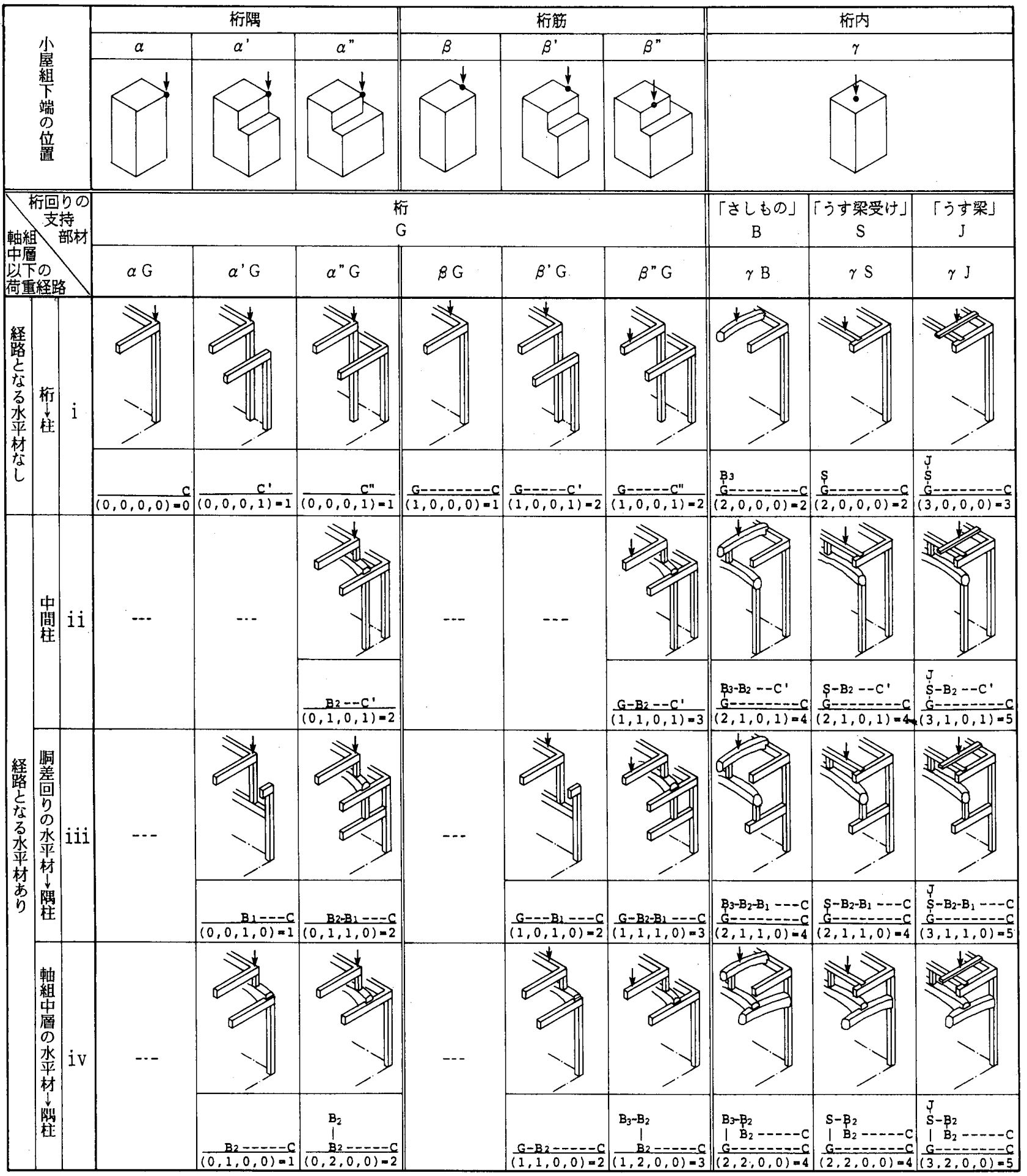

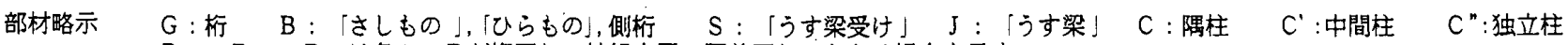
$\mathrm{B}_{3}, \mathrm{~B}_{2}, \mathrm{~B}_{1}$ は各々，Bが桁回り，軸組中層，胴差回りにかかる場合を示す。

小屋荷重の経由部材数 $\left(\mathrm{n}_{3}, \mathrm{n}_{2}, \mathrm{n}_{1}, \mathrm{n}_{0}\right)=\mathrm{n} ; \mathrm{n}=\mathrm{n}_{3}+\mathrm{n}_{2}+\mathrm{n}_{1}+\mathrm{n}_{0} \quad\left[\mathrm{n}_{3}=0,1,2,3 ; \mathrm{n}_{2}=0,1,2 ; \mathrm{n}_{1}=0,1 ; \mathrm{n}_{0}=0,1\right]$ $\mathrm{n}_{3}$ : 桁回りの経由部材数, $\mathrm{n}_{2}$ : 軸組中層の経由部材数, $\mathrm{n}_{1}$ : 郮差回りの経由部材数, $\mathrm{n}_{0}$ : 中間柱への経由部材数 
しのない $\alpha, \beta, \gamma$ が対応する。また，屋根替え後の瓦 苜の「まえいえ」には，図のすべての分類が対応し，亡

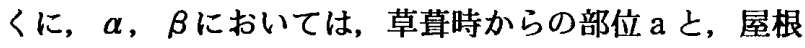
替え後の部位 $\mathrm{b} ， \mathrm{c}$ が考えられる。なお， $\beta$ ”には，主 架構の張り出しが一方向の場合と二方向の場合の雨方が 考えられるが, ともに, 上屋析を水平構面 $\mathrm{H}_{2}$ 古支持し ている点で同様である。以下の分析では図の最上段の* を付した模式図に示す形式を各分類の略示とする。

\section{（3）小屋荷重の伝達経路の類型化}

図一 7 には，横方向に，軸組上端と小屋組の関係を， 図－6に示した小屋組下端の位置と，小屋組下端を直接 支持する析回りの部材により分類した。また, 緥方向に は, 軸組中層以下の部材構成を，小屋荷重を伝えるため に有効な水平材の有無と小屋荷重が最終的に経由する部 材により分類した。すなわち, 縦方向の i には, 荷重が 析回りから直接柱に伝えられるものを配し，ii〜 ivには, 荷重伝達のために水平材が用いられているものを配して いる。このうち, ii 中, 中間柱に荷重が伝えられるもの, i i i は, 调差回りに入った水平材から隅柱に荷重が伝え られるもの, ivは, 軸組中層の水平材から隅柱に荷重が 伝えられるものである。

また，図一 7 には，縦横の分類に該当する部材構成を 模式図により示した。すなわち，これらの類型の配圆は， 軸組における小屋荷重の伝達経路を, 横方向における小 屋組と軸組上端の関係, 縦方向における軸組内部の構成 の両軸により系統的に表現したものであるといえる。さ らに，図一 7 には, 各類型における小屋荷重の経由部材 を軸組の各高さごとに略号で表示し, その部材数により 数量化した。すなわち, 析回りの水平材 $\left(\mathrm{n}_{3}\right)$ ，軸組 中層の水平材 $\left(\mathrm{n}_{2}\right)$, 胴差回りの水平材 $\left(\mathrm{n}_{1}\right)$ の 3 層および, 胴差回りょりも下部に位置する隅柱以外の柱 （n。）の4区分について経由部材数を示し，それらの 和を併記した。なお，調查住宅においてはn。には中間 柱のみが相当する。 $\mathrm{n}_{3}$ の最大值は，「うす梁」，「う す梁受け」，桁を経由する $3 ， \mathrm{n}{ }_{2}$ の最大值は, 軸組中 層の水平構面上の「さしもの」と, 垂直構面上の部屋境 の「さしもの」または側析を経由する $2, \mathrm{n}$ ，の最大值 は,「ひらもの」を経由する $1, \mathrm{n}$ 。の最大值は, 中間 柱を経由する 1 である。各類型の配列については, 経由 部材の総数が図の左上から右下に向かい次第に増すよう に並べており, 図の左上の $(0,0,0,0)$ を, 最も 単純に荷重を伝える形式すなわち隅柱以外に経由部材の ない形式, 図の右下の（3，2，0，0）を, 最も経由 部材が多く, かつ経由部材が上方に集まっている形式と している。

図一 7 における各類型について，横方向の並び方を軸 組と小屋組の関係から見れば，右方ほど荷重を側方に分
散させるために経由部材が多くなっており，小屋組下端 の位置の恣意性に対応しうる構成であるといえる。また, 図の縱方向の各類型の並び方を軸組架構の開放性から考 えれば, 最上段の $\mathrm{i}$ の列の架構は, 上方へは開放的であ るが，小屋組下端の位固により，側方への開放性が影響 を受ける構成である。すなわち，上屋と主架構が範用の 等しい $\alpha, \beta, \gamma$ では, 荷重を析から柱に伝えることが できるので，側方への開放性を確保できるが，上屋と主 架構の範囲が一致しない他のものでは, 中間柱, 独立柱 が立つために，側方への開放性が妨げられる。ゆえに， i の列に属する軸組は, 小屋組への依存性の強い架構形 式であるといえる。これに対して，ii以下の列では，軸 組中層以下に配された水平材に一旦荷重を伝えるため, 上方への開放性は i の列に比べて低くなるが, 㑡方への 開放性については, 軸組中層以下に伝えられた荷重を, 単位架構の境界のどの高さで処理するかにより, 上屋と 主架構の範囲の相違とは無関係に開放の度合を選択する ことができ, 軸組の部材構成が小屋組との関係から独立 しているということができる。

\section{4. 調查住宅における架搆の変化過程}

\section{(1) 分析方法}

図－8は，調查住宅における小屋組下端の配置を析回 りの伏図により例示したものであり，小屋組下端の位置 （以下，荷重点と呼ぶ）には，析隅，桁筋，桁内のもの が並存している。以下，これらの荷重点からの荷重が全 体として軸組の各部材にどのように経由されるかを，各 点ごとに, その荷重の伝えられる経路の割合を設定して 分析をすすめる。分析の前提として, 一荷重点から伝わ る荷重は, その荷重点が位置する単位架構の範囲内に伝 わるものと仮定する。また，分析対象については，析隅， 桁筋, 析内の選択性の生じうる小屋組内部の荷重点を扱 うものとする。ゆえに, 内部の小屋組とは独立して立ち 上がっていると見なされる瓦苜の妻面の小屋組構面, た とえば図ー 8 における 1 通りおよび 6 通りの荷重点は分 析対象から除外した。ただし，草草の妻側の扠首尻につ いては，屋根形状が入母屋であるために妻側の双首が内 部の小屋組構面とつながっている（図一 1 参照）ので, これは分析対象に含めた。

図－9には，単位架構の部材構成を例示し，荷重点 $p$, $\mathrm{q}, \mathrm{r}$ の各々について, その荷重経路と, 図一7に示し た各類型に当該する経由部材数を示した。この際，水平 材が交差している場合, その交点にかかる荷重は両水平 材に伝わるものと見なした。また，水平材の上に立てら れた束については, 柱のように独立して荷重を受ける部 材とは異なり，水平材と一組になって荷重を伝えるもの と考え, 荷重経路の部材数に含めないものとした。 
ついで, 各々の経由部材数を, 荷重の到達する単位架 構の辺数により係数を設定して併記した。これは, 単位 架構の一辺すなわち隅柱間のスパンに, 小屋組の支持部 材がどのような形式で入るのかということが, 軸組の空 間構成に与える影響を端的に示しうると考えたためであ る。すなわち, 図の $\mathrm{p}$ の荷重は, 隅柱一部材のみに伝え られるので係数を 1 とし， qの荷重は，軸組中層 II片 方向に配された「さしもの」B 2 により, 単位架構の対 辺 $\mathrm{q}_{1} ， \mathrm{q}_{2}$ に伝えられるので，係数を $1 / 2$ とする。ま た， $\mathrm{r}$ の荷重は，軸組中層 II両方向に配された「さし もの」 $\mathrm{B}_{2}$ により, 単位架構の四辺 $\mathrm{r}_{1} \sim \mathrm{r}_{4}$ に伝えら れるので, 各辺の係数を $1 / 4$ とする。ただし, 図の $\mathrm{r}_{2}$ のように, 単位架構の一辺に到達する荷重を複数の異な る部材が負担する場合には, 当該する部材数によりさら に係数を配分するものとする。以下，この係数を経由係 数之呼び, 経由係数之経由部材数の積和 $\mathrm{n}_{\mathrm{p}}, \mathrm{n}_{\mathrm{q}}$, $\mathrm{n}_{\mathrm{r}}$ を小屋組下端 1 筒所の経由部材数と定める。

以下, 図-9 の要領にしたがい, 調查住宅における小 屋荷重の経路を，小屋組下端 1 箇所あたりの平均值によ り分析する。これは, 軸組に分散する荷重経路を, 荷重 経路の起点となる小屋組下端を基準とした割合に置き換

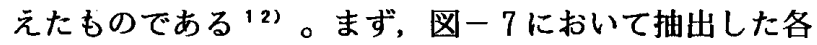
類型への対応がどのような割合で分布しているか, 次い で, 軸組の各高さにおいて平均的にはどの程度の経由部 材数になっているか，の二点について，各棟ごにに数值 化し，屋根形式ごとに年代変化の傾向を述べる。

（2）荷重経路の分布による分析

図-10には，調查住宅の各棟について，図一7に示し た各類型に対沁する荷重点ごとの経由保数を振り分け, その累積值を小屋組下端の総数で除した比率を示し，こ れらを屋根形式ごとに分けて年代順に配した。すなわち， 図-10は一棟の架構におりる荷重経路の種類の多宾之そ の割合を表現したものであるといえる。たとえば，線分 が各欄の横方向いっぱいに引かれている場合には，一棟 の架構の荷重経路が，すべて当該する類型の示す形式に なっていることを示し，また，各欄に線分の分散してい るものは, 一棟のなかで多様な荷重経路が生じているこ とを示している。

図ー10では，図ー7における類型の該当しない欄を除 いたうえで，屋根形式ごとに，図一6に示される部材構 成上該当する領域を示している。すなわち，(1)に示す草 咠の「すや」において対応可能な領域は，双首尻が析上 に位置する制約から， $\alpha \mathrm{G}, \beta \mathrm{G}$ の列に限定され，(2)に 示す屋根替え後の「すや」では, 析内に配される「うす 梁受け」，「うす梁」の上にも小屋束が立つことが可能 になるので， $\gamma \mathrm{S} ， \gamma \mathrm{J}$ の列が加わる。また，(3)に示す 当初からの瓦惪の「すや」では，析回りに「さしもの」
をかけるものが現れているので， $\gamma \mathrm{B}$ の列がこれに加わ る。(4)に示す草草の「まえいえ」では， $\alpha^{\prime} \mathrm{G} ， \alpha^{\prime \prime} \mathrm{G}$, $\beta^{n} \mathrm{G}$ の列が対応し，(5)に示す屋根替え後「まえいえ」 では， $\gamma \mathrm{B}$ 以外のすべての列が対応可能である。

このような, 屋根形式による荷重経路の対応可能な領 域のなかで, 調查住宅に実際に見られた荷重経路の分布 がぞの程度の割合であるかに注目し, 以下, 屋根形式ご とに考察する。
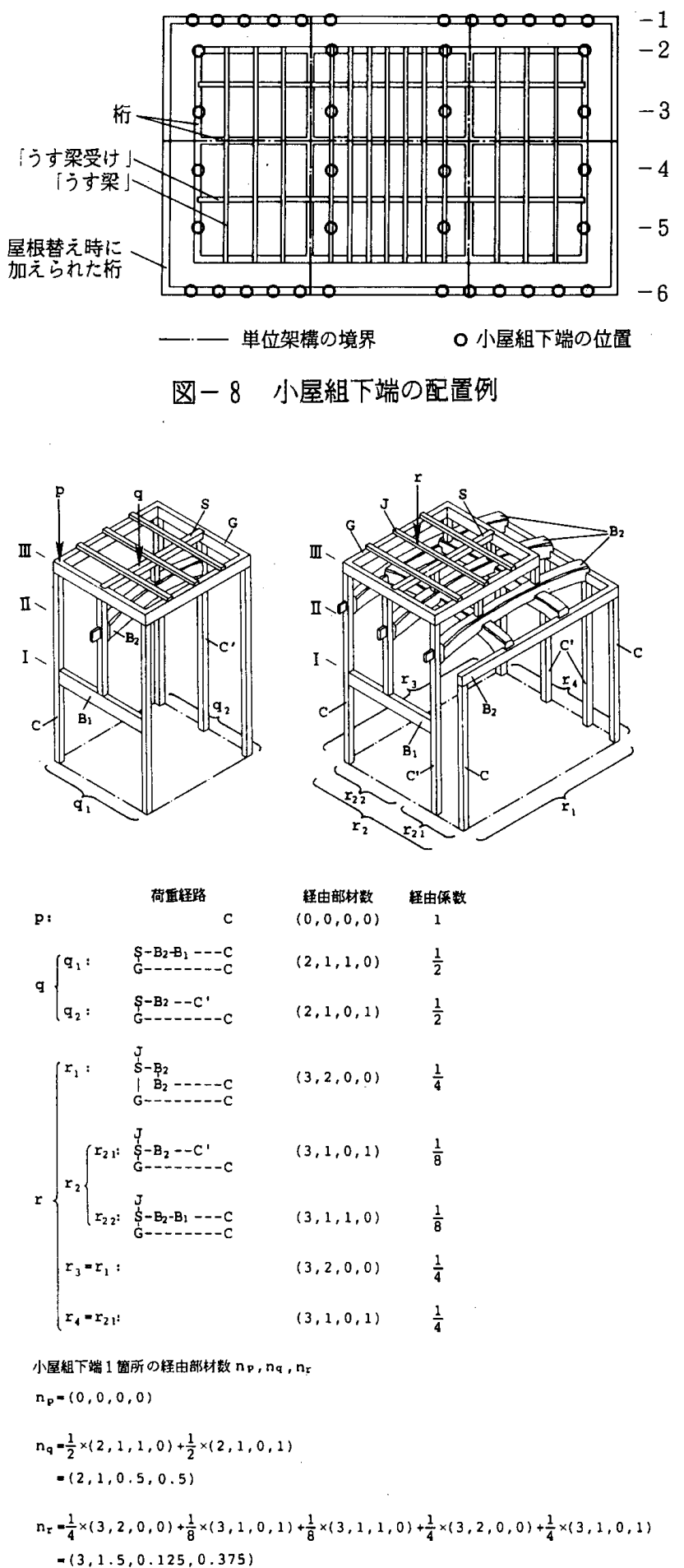

图-9 小屋荷重の経白部材数の計算方法 
草苜の「すや」では，どの家屋においても，小屋組下

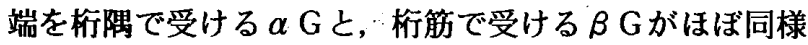
の比率で分布している。屋根替え後「すや」では，桁内 で小屋組を支持しているものは少なく（8 棟のうち $\gamma \mathrm{S}$ に相当する 2 棟のみ)，当初から瓦苴の「すや」では， 屋根替えした「すや」とは異なり, 荷重経路が柯内 $\gamma \mathrm{B}$, $\gamma \mathrm{S} ， \gamma \mathrm{J}$ の各欄に広く分布しており（桁隅，桁筋だけ で小屋束を受けているのは 23 棟中 1 棟のみ），これらの 例では，「うす梁」の成が草草のそれに比べ増している ものがあった ${ }^{13)}$ 。また，当初から瓦惪の「すや」にお いては，年代が下ると $\gamma \mathrm{B}$ ，すなわち析内の「さしもの」 により小屋束を受けるものが増えており，とくに，r B とi の対応が多くなっている。この形式は，図一7の模 式図に示すように，析回りの「さしもの」の下方の部材 を小屋組からの制約を受けずに構成することができ，そ れゆえ軸組内に 2 層の空間を得ている。しかも，「うす 梁受け」, 「うす梁」による構成 $\gamma \mathrm{S} ， \gamma \mathrm{J}$ と i の対応

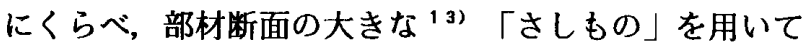
いることも小屋組の支持において合理的であるといえる。 ゆえに，この $\gamma \mathrm{B}$ と $\mathrm{i}$ の対応は, 軸組内に 2 層の空間を 獲得する実利と, 小屋組を有勃に支持するための架構の 合理性が両立した形式であるととらえることができる。

一方，草苜の「まえいえ」において，析を直接柱で受 ける $\mathrm{i}$ の列のものが少なく, 大部分が小屋組下端を水平 材で受ける形式ii，iii，ivになっていることは，図一7 を参照すれば，軸組中層以下に水平材を設けることによ り，上屋と主架構がずれた部分での柱立ちを回避してい るということであり，むしろ，年代により，iiからivへ の移行, すなわち, 軸組中層の梁組を経た荷重を受ける 垂直構面の部材の高さが上方に変化する傾向が見られ, 単位架構の境界の側方への開放性を高めてゆく段階であ るということができる。なお，「まえいえ」の屋根替え 後については, 部材構成上の対応可能な領域に偏りなく 広く分布しており，とくに顕著な傾向は見られない。

（3）荷重経路の高さによる分析

図ー11には，図ー 9 で設定した小屋組下端一箇所の経 由部材数の総和を，小屋組下端の総数で除した値，すな わち，桁回り，軸組中首，胴差回りの 3 層の水平材，お よび中間柱の計 4 区分における平均的な小屋荷重の経由 部材数を平均経由部材数 $\left(\mathrm{N}_{3}, \mathrm{~N}_{2}, \mathrm{~N}_{1}, \mathrm{~N}_{0}\right)$ 之 定め, 各棟ごとに年代に対応させ，屋根形式ごとに，す なわち，草草，瓦惪の相違および「すや」，「まえいえ」 の相違により区別して示した。

図-11から, 小屋荷重が軸組の各層の部材にどの程度 の割合で経由しているのかについて, 以下，屋根形式ご とに年代変化の傾向を述べる。

草惪では，図一11で「すや」（図中の○），「まえい

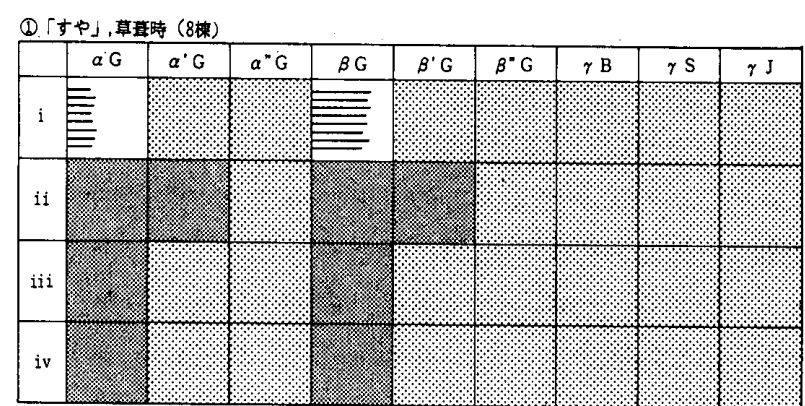

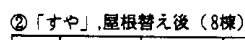

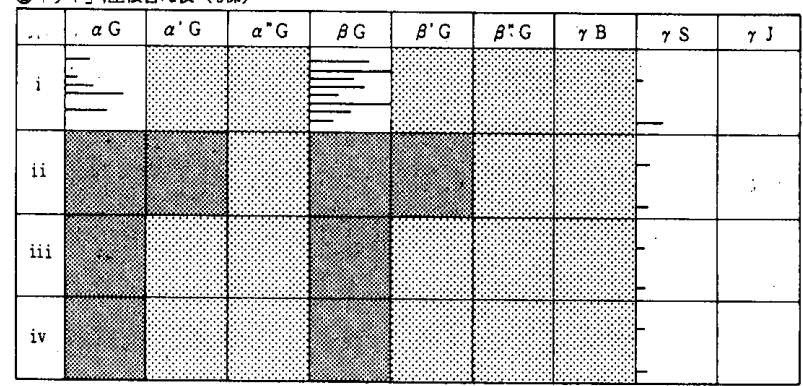

(3)门小!当初から桼 (23娻)

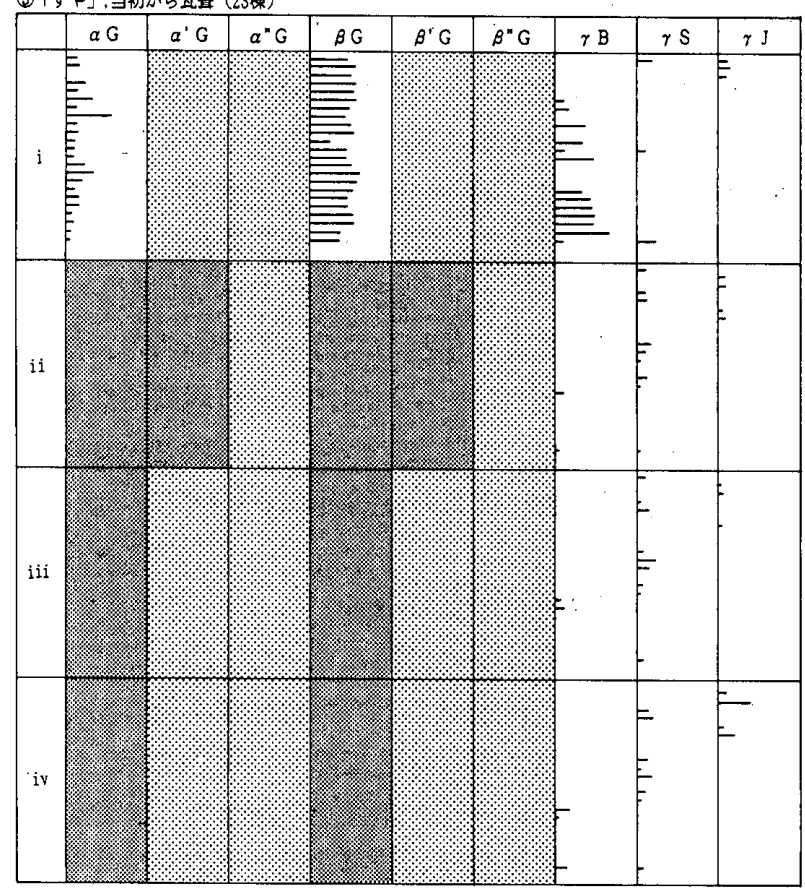

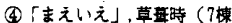

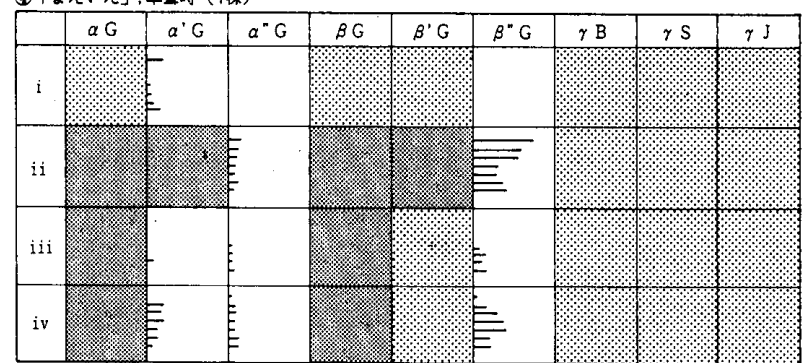

(5)「まえいえ」，尿柦替元後（4娻）

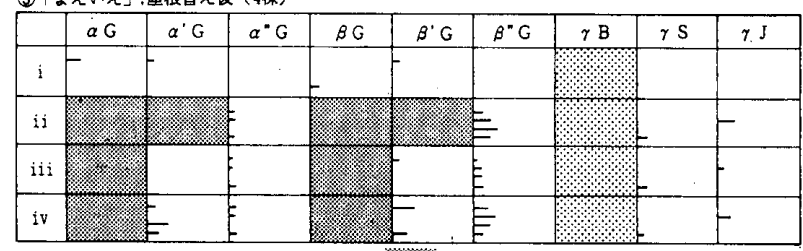

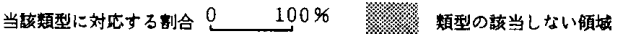

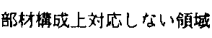

図-10 調查住宅における荷重経路の分布 
え」（図中の四）ともに，年代にかかわらず，析回りの 水平材の平均経由部材数 $\mathrm{N}_{3}$ は 1 以下となっている。こ れは, 両者ともに, 竣工当初は双首尻を析で受ける形式 であるため, 荷重経路が，隅柱上で直接荷重を受ける場 合（この場合は桁回りの経由部材数 $\mathrm{n}_{3}=0$ ）か，また は析を経由し隅柱に荷重が伝えられる場合（この場合は 析回りの経由部材数 $\mathrm{n}_{3}=1$ ）のいずれかであるため, これらの組み合わせとして一棟の架構の平均値 $\mathrm{N}_{3}$ が 0 と 1 の間の值を示すことによっている。なお,このこと は, 図一 7 において, 桁隅, 桁筋の全類型に共通して桁 回りの水平材の経由部材数 $\mathrm{n}$ s が 1 以下となっているこ とにも表れている。

そこで，草惪における「すや」，「まえいえ」の軸組 中層以下の経由部材数 $\mathrm{N}_{0}, \mathrm{~N}_{1}, \mathrm{~N}_{2}$ の値の年代変化

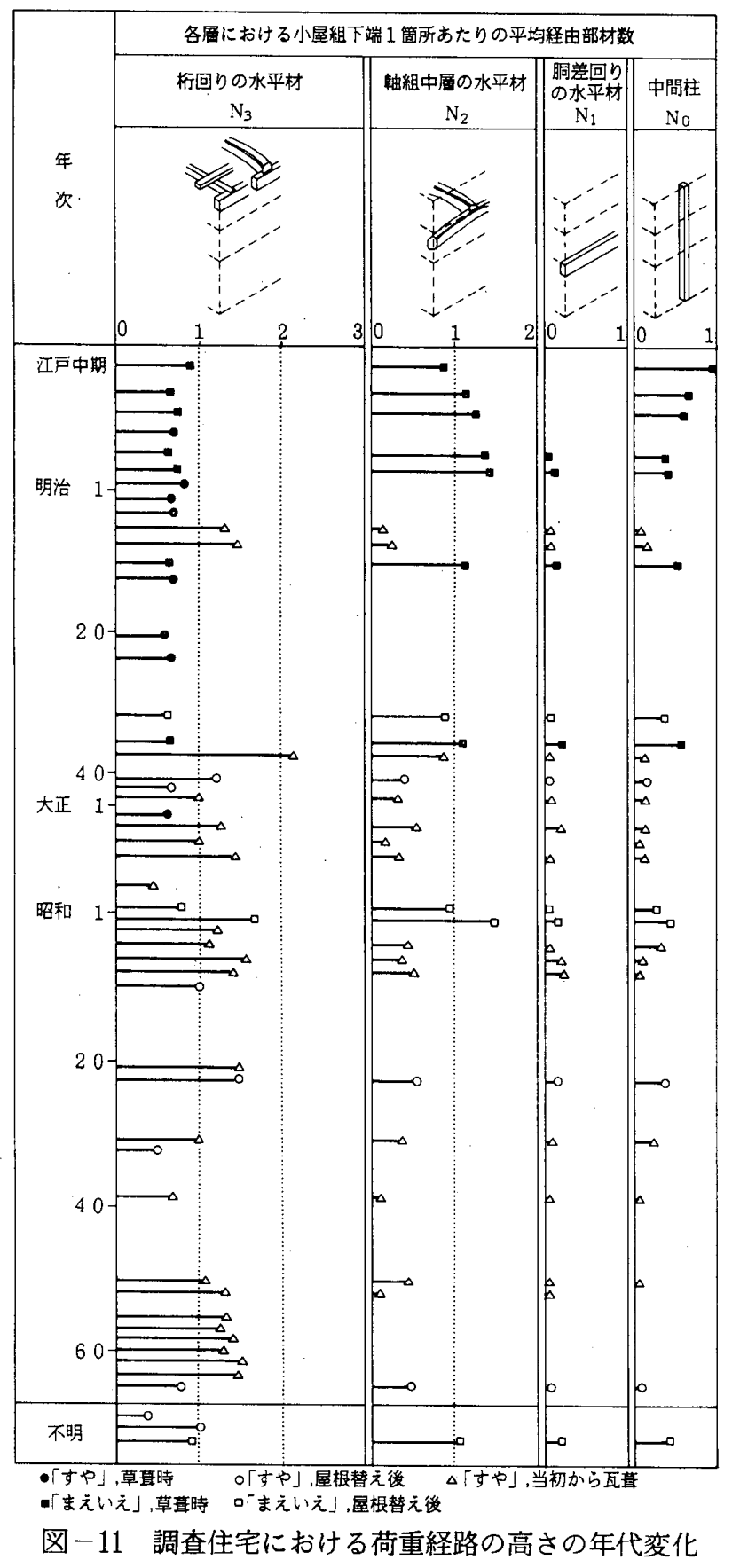

を見ると，まず，草惪時の「すや」では，図一11でN 。， $\mathrm{N}_{1} ， \mathrm{~N}_{2}$ の值がすべて 0 となっている。このことは, 草苜における双首尻が，すべて柱頭をつなぐ析通りに位 置するため, 軸組中層以下に小屋組の支持部材がなくと も，析と隅柱による簡素な構成で小屋組が支持されてい ることを示している。

つぎに，図一11において草蒀の「まえいえ」の変化を 見ると，「まえいえ」が竣工した江戸中期から明治期に かけては $\mathrm{N}_{0}$ の值が成じ， $\mathrm{N}_{1}, \mathrm{~N}_{2}$ の值が増加する㑯 向が見られる。「まえいえ」の部材構成においては, $\mathrm{N}_{0}, \mathrm{~N}_{1}, \mathrm{~N}_{2}$ の值は, 桁を経由した荷重が, その下 方に張り出した軸組中層の水平材に伝えられた後, 側方 に立ち上がる垂直構面のどの高さを経由するかにより異 なってくる（図一5において「まえいえ」を表した 2,3 の架構図を参照）。したがって，草惪時の「まえいえ」 は，江戸中期において軸組中層の水平材から中間柱に多 く伝えられる形式であったものから，次第に中間柱の割 合が減じ, より高い層の部材に置き代わってゆく㑯向が 見られる。これは, 軸組中層の水平材を保持しながら, 側方へ空間を開放してゆく過程を示しているといえる。 一方，瓦莫については，屋根替え住宅（図-11の○, 口) では, 桁回りの水平材の平均経由部材数が草草時に 比べ，それほど増していない（12棟のうち $\mathrm{N}_{3}$ が1を超 えているものは 3 棟のみ）。これに比へ，当初からの瓦 莫では, 屋根替え住宅よりも荷重の経由する桁回りの水 平材が多くなっている（23棟のうち $\mathrm{N}_{3}$ が 1 を超えてい るものは18棟）。 $\mathrm{N}_{3}$ が1を超えるということは, 小屋 束が析以外の部材の上に立ち，当該部材と析との少なく とも 2 部材を小屋荷重が経由するものが現れていること を意味している。すなわち, 屋根替え時には, 草直の小 屋組に対応した軸組構成のままで小屋組が取り替えられ たので，草草時に小屋荷重を受けていなかった桁内の部 材の上には小屋束を立てにくかったということが推察さ れる。

また，当初からの瓦惪（図一11の $\triangle$ ）については，明 治後期から昭和前期にかけては, 析回りの水平材の平均 経由部材数とともに他の層の平均経由部材数が多いもの も現れている。これに対して, 昭和後期の当初からの瓦 咠では，桁回りょりも下方の経由部材は著しく減ってい る。このことから, 当初からの瓦苜では, 小屋荷重を軸 組の最上部で受けたのち，その下方にも梁組を配した重 層的な構成とするか，あるいは，その下方を開放し，空 間の上方への自由度を得るかという点において架構形式 の選択がなされていると見ることができる。

図一11を全体として見れば，草惪，瓦草のいずれにお いても，年代により， $\mathrm{N}_{0} ， \mathrm{~N}_{1}, \mathrm{~N}_{2}$ すなわち中間柱 および胴差回り，軸組中層の水平材による支持が次第に 隇じ， $\mathrm{N}_{3}$ すなわち析回りの水平材により小屋組を支持 
する場合が多くなっている。このことは, 小屋荷重が, 軸組のより高い位置の部材に伝えられるようになったこ とを意味している。

以上から，調查住宅における荷重経路は，年代的に次 第に軸組の上層に移行する倾向が認められるということ ができ、これに伴う軸組と小屋組の関係は，初期の草苜 における，軸組中層以下の諸部材に多くを負った形式か ら，竣工当初草咠のものでは，屋根替えによる変化を含 めても，側方への空間の自由度を得る過程を示すにとど まったといえるが，当初からの瓦苜においては，各層に おける梁組の配置の多様さが，上方への空間の自由度の 確保を可能にしたということができる。

\section{5.まとめ}

本研究では, 石川県鹿西町周辺の木造住宅において, 小屋組下端と析の位置関係および軸組内部の部材構成に 着目して軸組を伝わる小屋荷重の伝達経路を類型化し， 一棟の家屋における軸組と小屋組の関係を，荷重経路の 選択のしかたと, 軸組の各層の平均的な経由部材数によ り数量的に表現することができた。

その結果, 屋根形式ごとに, 部材構成上可能性のある 荷重経路の種類のなかで，調查住宅の選択した形式の範 囲およびその割合を明らかにした。また，各層における 平均的な荷重経路については，年代的に，軸組の上層に 移行する傾向が認められ，これに伴う草苴の変化は，屋 根替えによる小屋組の変更を含めても，側方への空間の 自由度を得る過程を示すにとどまったのに対して，当初 からの瓦草のものでは，軸組構成を重層的な梁組とする か, 上方への空間の自由度を確保するかの選択が可能で あるような, 各層における梁組の配置の多様さが生じて いることがわかった。

今後は, 他地域における住宅架構を, 本研究において 提示した分析方法に照合し，その有効性を探っていきた い。

注

1）康西町の能登部下, 徳丸, 能登部上, 西馬場の 4 地区を 中心に, 羽咋, 七尾, 鹿島, 高兵などの周辺地域を調查 対象とした。

2) 本研究の「さしもの」は，文触2)の「差しもん」：(2)の 『石川県能登地方の民家において，茅茸き屋根の小屋梁 を示す呼称』に相当し，通常「さしもの」と呼ばれる差 呞居とは異なる部材である。

3）実测謂查については，昭和59年度文部省科学研究費粉合 A（代表・内田祥哉）により行ったものに, 筆者らの追 加調查により，資料を加えたものである。

4) 文献2)

5 ）文献1)によれば，上屋は，『合掌や小屋梁を支えている
主体構造を指す呼称』とされている。本研究では，単位 架構の占める範囲と区別するために，小屋組部材が部材 構成上連続的に占めている範囲とする。ゅえに，草苜に おける追双首の占める部分や，瓦苜で外観上屋根が下屋 とつながっていても構成部材が継いである場合は，上屋 とはみなさない。

6）文献1)では，析を，外通りの柱またはこれに代る束に支 持され，垂木を受けている水平材を指すものとしている が、本研究では，垂木を受けていない「地の析」，「中 行」についても，柱頭をつなぐ配置や，材の断面形状が 一般の析と同様であることから，側析とともに析として 広義に扱うものとする。

7）本研究上の仮の呼称。「うす梁」を受ける，の意から。 現地での呼称はとくにない。

8）文献1)によれば，『富山県東砥波群地方や石川県能登地 方などの農家において屋根裏室の床となる笡子を敷くた めに架ける横架材の呼称』を，うす梁としている。

9）文献1)によれば，能登地方では，前者を「素家」または 「素家建て」，後者を「真家造り」と称するとされてい る。現地では，後者を「まえいえづくり」と呼ぶが，前 者の呼称はとくになかった。本研究では，できるだけ現 地の呼称を用い，「すや」，「まえいえ」と呼び分ける ものとした。

10）「うす梁」を小屋束の支持材として用いた例は，38棟中 6 棟（屋根替え後が 1 棟, 当初からの瓦惪が 5 棟）であ り，当該する事例は少数であるが，草苜時に小屋荷重を 受けていなかった「うす梁」が，瓦苜においては小屋組 を受ける部材としてその働きが転じている可能性を考慮 する意図により，分析範用に含めた。

11）一般的に上屋・下屋からなる架構では，下屋梁が用いら れることにより，屋根荷重が側析を起点として下部に伝 えられる場合も考えられるが，調查住宅においては図一 3 に示した架構の範囲から下屋梁が外側に張り出す事例 が認められなかったため考慮しなかった。この点に関し ては，今後他の地域の架構との比較において分析方法を 検討するものとしたい。

12 ）本研究は，荷重の配分量を扱ったものでなく，荷重の分 散する経路を扱ったものであるので，力学的な要素すな わち部材の断面，仕口，長さなどの要素を考慮外として， 部材の位置関係としての傾向を示すことを意図している。

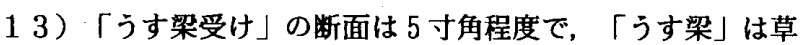
革のもので成 2 寸, 幅 5 寸程度, 当初からの瓦咠では明 治期には草草之同程度, 大正期以降は，「うす梁受け」 とさほど変わらない 5 寸角程度となっている。また「さ しもの」は径 8 寸 1尺 2 寸程度の丸太を太鼓に落とし， 幅 $6 \sim 8$ 寸程度としている。

\section{参考文献}

1）日本建築学会民家語彙集録部会編：日本民家語彙集解, 1985.10

2) 財団法人文化財建造物保存技術協会編 : 重要文化財座主 家住宅修理工事報告書, 1974.11

(1993 年 7 月 7 日原稿受理, 1994 年 2 月 3 日採用決定) 